\title{
The Phenomenon of Private Military Companies in the Military and Power Policies of States in the 21st Century ${ }^{1}$
}

\author{
K. Kurilev, N. Parkhitko, D. Stanis, E. Martynenko
}

Konstantin Kurilev - PhD, Assistant Professor, Peoples Friendship University of Russia; 6 MiklukhoMaklaya Street, 117198 Moscow, Russian Federation; E-mail: kurylev_kp@rudn. university.ru

Nickolay Parkhitko - PhD, Senior Lecturer, Peoples Friendship University of Russia; 6 MiklukhoMaklaya Street, 117198 Moscow, Russian Federation; E-mail: parkhitko_np@rudn. university.ru

Daria Stani - PhD, Assistant Professor, Peoples Friendship University of Russia; 6 Miklukho-Maklaya Street, 117198 Moscow, Russian Federation; E-mail: stanis_dv@rudn.university.ru

Martynenko Elena - Vice-rector of RUDN University; Professor, Head of the Chair of Theory and History of journalism; 6 Miklukho-Maklaya Street, 117198 Moscow, Russian Federation; E-mail: martynenko_ev@pfur.ru

Two main issues are considered in this article. The first is the changing historical and legal status of private military companies (PMCS). Emerging after the end of World War II, the PMC phenomenon became wellestablished by the mid-1990s. In the first decade of the 21st century, PMCs not only engaged in military activity in different regions of the world but also participated as independent economic actors capable of occupying a certain niche in the military segment of the world economy. Following this review, the article examines the practical activities of PMCs drawing on the example of the conflict in Ukraine during the civil war that began there after the coup d'etat of February 2014 and which saw the removal of the legally elected president $V$. Yanukovych and the rise of nationalist radicals to power. It should be noted that the Ukrainian crisis is only one of many examples of the use of PMCs. Moreover, as demonstrated in this study, the most powerful PMCs in the world are represented in the territory of Ukraine, pointing to the extreme importance of the processes occurring in Ukraine from the view point of the interests of the dominant actors in the modern international system involved in Ukrainian affairs.

Key words: Private military company (PMC); Mercenarie; Montreux document; Ukraine; Armed conflict; Civil war

For citation: Kurilev K., Martynenko E., Parkhitko N., Stanis D. (2017) The Phenomenon of Private Military Companies in the Military and Power Policies of States in the 21st Century. International Organisations Research Journal, vol. 12, no 4, pp. 130-149 (in Russian and English). DOI: 10.17323/19967845-2017-04-130

\section{Introduction}

States have lost their monopoly on the use of military force. This erosion of direct state control constitutes one of the principle modern challenges facing international

${ }^{1}$ The editorial board received the article in May 2017. 
security. A few decades ago, most tescountries relied on their own armed forces to implement military policy; armies were staffed with professional soldiers as well as drafteesconscriptssis. However, in the wars and military conflicts of the 21 st century, the role of the units of non-governmental structures has been growing. Today, PMCs are an equivalent legal entity alongside the armed forces of various states, and are widely used in international conflicts. PMCs are structures authorized by states to solve special tasks. Currently, PMCs are on equal footing with regular armies. Moreover, based on expert opinions, such structures will play an increasingly important role in armed conflicts and wars in the future. PMCs are the object of the study in this article. The subject of the study is the policy of states using PMCs in certain conflicts occurring in places around the world, exclusively in accordance with their own foreign policy interests. Given the "national" origin of each individual PMC (in this context, it is appropriate to use the English word "nation" in the sense of "state, country"), despite their apparent commercial autonomy, their actions are still directly politically dependent on the interests of the state in the world arena.

As for the methodology used in the study, the authors relied on the typological method, classifying each PMC reviewed based on its regional (zone of activity and interests), national (country of origin and preferential nationality of staff) and financial (large PMC affiliated with the oil business or small PMC performing private orders) principles. It also used the comparative method, which allows us to compare the studied PMCs with each other, and the modeling method, identifying the causal relationship between certain political events preceding the emergence of a certain conflict in a particular country (region) and the inclusion of PMCs in a conflict on the side of the government/insurgent forces, depending on the political environment.

The main conclusions regarding both aspects of the study are formulated in the final section. General conclusions are drawn about the new role of PMCs in contemporary international relations, taking into account their adaptation to the changed realities of the 21 st century.

\section{Private military companies:}

\section{The problems of terminology and definition.}

One of the main modern challenges facing international security is the erosion of the state's monopoly on the use of military force. Even a few decades ago, most of the world's states, when implementing their military policy, relied on their armed forces, which were either professional fighters or conscripts. However, in the wars and military conflicts of the 21st century, the role of units of non-governmental structures has been growing. Today, PMCs are an equivalent legal entity alongside the armed forces of various states, which are in wide use, in practice, throughout the world. PMCs are structures authorized by states to solve special tasks. These days, PMCs occupy an equal position with regular armies. Moreover, based on expert opinions, such structures will play an increasingly important role in armed conflicts and wars in the future. 
At present, both in Russian and foreign historiography, there is no uniform definition of the concept of "private military company" and therefore very often there is confusion regarding the definition of what a PMC is. There are numerous names for those who for one reason or another start working for a PMC: soldiers of fortune, wild geese, etc. However, the term "mercenary" is used most often.

According to one of the definitions, "A PMC is a registered private high-profit commercial structure staffed with high-class technical specialists, controlled by the state and acting in the interests of the state ...”2

According to another definition, a PMC is "a highly organized structure whose main task is to ensure combat operations (logistics, collection and destruction of unexploded ordnance and mines, removal from the battlefield and repair of damaged equipment, supplying food for soldiers, sustainment, protection of military facilities and warehouses, prisons, etc.)." PMCs are created and used in the interests of the state. ${ }^{3}$

There is another definition of PMC, which goes as follows: "PMCs are non-governmental organizations rendering military services on a fee-for-service basis to individuals and legal entities, as well as to states; military services are understood to include specialized services related to military activities, including military operations, strategic planning, intelligence, operational or logistical support, the training of military personnel, logistics, etc." 4

There is also a more detailed approach that refers to PMCs as "commercial organizations created to profit through the provision of contract-based military and paramilitary services operating primarily outside the country of origin whose employees are not government employees." 5

Thus, it is clear that, indeed, there is no unambiguous definition of the term "private military company." From the above definitions, it is clear that the existing definitions are not even accurate, since states comprise the main customers of their activity, and PMCs are most often registered within that state. Accordingly, in essence, they are not a private military force but one resulting from the outsourcing of state structures, and they are an instrument of the state's foreign policy.

\section{The History of the PMCs' development, from hired militia of the Middle Ages to the private armies of the 21st century}

The historical stages of modern PMC development can be nominally divided into three periods: 1940-1970s, 1980-1990s, and from the 1990s until now. Naturally, the division is rather relative because it is very difficult to identify rigid periods for the transi-

${ }^{2}$ N. Tsepkov. Private Military Companies: A Brief Overview of International and Russian Regulation. Available at: https://zakon.ru/blog/2015/12/14/chastnye_voennye_kompanii_kratkij_obzor_mirovogo_i_ rossijskogo_regulirovaniya (accessed 10 April 2016).

${ }^{3}$ A. Alikin. PMCs Are a Very Effective Tool of Influence. Available at: http://rusplt.ru/society/voenniechastniki-8795.html (accessed 10 April 2016).

${ }^{4}$ A. Volevodz (2009) On International Initiatives in Legal Regulation of the Activities of Private Military and Security Companies. International Criminal Law and International Justice, no 1, p. 14.

${ }^{5}$ Y. Apukhtin (2009) Private Military Companies: a New Goal of Political Criminology. Criminology: Yesterday, Today, Tomorrow, no 2 (17). 
tion from one period to another. At the same time, a deep historical digression leads us to very interesting conclusions.

There is the opinion that "even the conquering of America by the conquistadors was their own private endeavor, as the Spanish kings granted them the right to get a buyback on the lands they conquered, as well as the right to own the lands themselves. A similar private endeavor precipitated the seizure of colonies in India and Southeast Asia by the British East India Company, and, for that matter, the French and Dutch East India companies." As researchers note, "The militia of Minin and Pozharsky was, in fact, a private army for state purposes. Tsar Ivan IV the Terrible hired a privateer flotilla under the leadership of Karsten Rhode, a Dane, for operations in the Baltic, while the Stroganov merchants hired an Ermak squad for solving their own economic task - the conquest of Siberia. Cossacks, in fact, were private armies, albeit in the civil service. The Imperial Russian Army was often aided by private hordes, e.g. Nogais."7

The emergence of mercenaries in the modern sense of the word received a powerful boost immediately after the end of World War II, when thousands of people who'd been professionally trained to kill remained unclaimed. As demand always generates supply, there became a market for these professionals, too. Commercial battle units demonstrated themselves as a single and formidable force for the first time during the suppression of the wave of national liberation movements in Africa. The result was a UN ban on mercenary activities. This ban was entered into the 1949 Supplementary Protocol I to the Geneva Convention for the Protection of War Victims. However, some countries did not ratify it, the United States in particular.

The remaining mercenaries were retrained into security structures. They dealt with the protection of both individual companies and entire governments. Private security companies gradually became a serious force for "dirty work" done at the behest of government agencies and terrorist organizations.

From the early 1990s, the role of already-mature PMC structures in local and regional conflicts increased sharply. This was facilitated by mass cuts of military servicemen both in Western countries in the 1990s and in the post-Soviet space after the collapse of the USSR. Since then, PMCs have only increased their influence and combat power by participating in military and peacekeeping operations along with different branches and types of armed forces.

In the early 1990's, for every 50 regular US military personnel there was only one PMC, but by 2012 this ratio had decreased to 10:1 and the proportion of PMCs is growing. There are several hundred private military and security companies operating in Afghanistan and Iraq alone, which employ more than 265,000 private contractors. $^{8}$

${ }^{6}$ O. Valetsky. Private Military Companies, Their Creation and Development - Experience in Iraq, Afghanistan, Africa and Other Regions of the World. Available at: http://artofwar.ru/w/waleckij_o_w/chvk. shtml (accessed 10 April 2016).

${ }^{7}$ S. Kanchukov. Private Military Companies - Help or Burden for Russia? Available at: http://www. iarex.ru/articles/28444.html (accessed 10 April 2016).

${ }^{8}$ Private Military Companies - Mercenaries of the XXI Century. Available at: http://politrussia.com/ vooruzhennye-sily/chastnye-voennye-kompanii-469/ (accessed 10 April 2016). 


\section{Legal characteristics of mercenary activities}

How well does the term mercenary describe those who work in PMCs? Let us turn to international legislation and see how it interprets the concepts. It should be noted at once that there is no such thing as a PMC in international law, although mercenaries are mentioned. Firstly, we are talking about the 1977 Additional Protocol I to the Geneva Conventions of 1949. In accordance with its Article 47, "a mercenary is a person who

1) is specially recruited locally or abroad in order to fight in an armed conflict;

2) actually takes direct part in armed hostilities;

3 ) is motivated to take part in the hostilities essentially by the desire for private gain and, in fact, is promised, by or on behalf of a party to the conflict, material compensation substantially in excess of that promised or paid to combatants of similar rank and function in the armed forces of that party;

4) is neither a national of a party to the conflict nor a resident of the territory controlled by a party to the conflict;

5 ) is not a member of the armed forces of a party to the conflict;

6) has not been sent by a State which is not a party to the conflict on official duty as a member of its armed forces." 9

As can be seen, along with financial criteria, mercenaries must also meet a number of other criteria. In particular, they cannot be a part of the armed forces of any of the parties to the conflict. In addition, they cannot be sent by a state that is not a conflicting party to perform official duties as a member of its armed forces.

In December 1989, the UN adopted the International Convention against the Recruitment, Use, Financing and Training of Mercenaries. This document, unlike the 1977 Additional Protocol I to the Geneva Conventions of 1949, defines mercenaries as not only persons directly involved in armed conflicts, but also any person who:

1) "is specially recruited locally or abroad for the purpose of participating in a concerted act of violence aimed at:

2) a) overthrowing a Government or otherwise undermining the constitutional order of a State; or

b) undermining the territorial integrity of a State;

4) is motivated to take part therein essentially by the desire to for significant private gain and is prompted by the promise or payment of material compensation;

5 ) is neither a national nor a resident of the State against which such an act is directed;

6) has not been sent by a State on official duty; and

7) is not a member of the armed forces of the State on whose territory the act is undertaken.” 10

${ }^{9}$ Additional Protocol to the Geneva Conventions dated 12 August 1949 concerning the Protection of Victims of International Armed Conflicts. Available at: https://www.icrc.org/rus/assets/files/2013/ap_i_rus. pdf (accessed 10 April 2016).

${ }^{10}$ International Convention against the Recruitment, Use, Financing and Training of Mercenaries. Adopted by General Assembly resolution 44/34 on December 4, 1989. Official Records of the General Assembly, 44th Session, Supplement No. 49 (A/44/49), pp. 425-428. 
It should be noted that the Convention against the Recruitment, Use, Financing and Training of Mercenaries was signed by $40^{11}$ countries and ratified by $30 .^{12}$

A similar definition of a mercenary is found in the Convention of the Organization of African Unity (now the African Union) for the elimination of mercenary activities in Africa. ${ }^{13}$

As can be seen, in order for a PMC worker to qualify as mercenary, they must meet all of the above criteria. Therefore, these definitions are regarded by many as ineffective. Accordingly, only some of the PMC staff participating in international military conflicts can be recognized as mercenaries. This is actually not something they desire, given that one of the features of the legal mercenary status is that the person participating in an international armed conflict will not have the status of a prisoner of war. This is indicated by the Geneva Convention on the Treatment of Prisoners of War of 1949, which lists persons who are eligible to the status of a prisoner of war.

In other words, international law defines mercenaries as war criminals and, if a mercenary is captured, theoretically he can be shot without a trial or record.

\section{Legal aspects of the regulation of PMCs. Major international documents}

It should be noted that currently there is no international legal instrument which would reflect and regulate the activities of PMCs. The documents that we discussed above do not mention this whatsoever. Thus, if we recognize that mercenary activities and the activities of PMCs are different phenomena, it turns out that the legal status of PMCs is not defined and not established due to gaps in the current legislation. ${ }^{14}$ In other words, PMCs are not subjects of international law or bearers of the obligation not to use force in international relations set forth in the UN Charter.

At the same time, there are certain legal norms regulating the activities of PMCs. "In the early 21st century, legal initiatives appeared that were aimed at strengthening the control over the activities of PMCs on the part of the government of Great Britain (Green Rareg-2002) and Switzerland, in conjunction with the International Red Cross (the so-called Swiss Initiative of 20026). Upon adoption, the initiative was endorsed by Australia, Austria, Angola, Afghanistan, Britain, Germany, Iraq, Canada, China, Poland, Sierra Leone, the USA, France, Sweden, Ukraine, and South Africa. These initiatives were aimed at:

${ }^{11}$ Angola, Azerbaijan, Barbados, Belarus, Belgium, Cameroon, Congo, Costa Rica, Croatia, Cuba, Cyprus, Democratic Republic of the Congo, Georgia, Germany, Guinea, Italy, Liberia, Libyan Arab Jamahiriya, Maldives, Mali, Mauritania, Moldova, Montenegro, Morocco, New Zealand, Nigeria, Peru, Poland, Qatar, Romania, Saudi Arabia, Senegal, Serbia, Seychelles, Suriname, Togo, Turkmenistan, Ukraine, Uruguay, Uzbekistan.

${ }_{12}$ The Convention was not ratified by Angola, Germany, Democratic Republic of the Congo, Congo, Morocco, Nigeria, Poland, Romania, Serbia, and Montenegro.

${ }^{13}$ Convention for the Elimination of Mercenarism in Africa, Organization of African Unity, Libreville, 3 July 1977, CM/817 (XXXIX), Annex II, Rev. 3 (entered into force 22 April 1985).

${ }^{14}$ Singer P. (2005) Outsourcing War. Foreign Affairs. 1 March. Available at: http://www.brookings.edu/ views/articles/fellows/singer20050301.htm (accessed 10 April 2016). 
A) Creating a single international body (secretariat) to monitor the activities of PMCs that has the right to prohibit their activities in "aggressor countries" and other states and has the ability to revoke their operating license as a punishment;

B) Instituting international control over the licensing system for PMCs;

C) Monitoring international bodies for the activities of PMCs with the development of agreements between countries that have such companies.

It was assumed that the functions of the international body (secretariat) for monitoring the activities of PMCs could include considering complaints about the companies in the event of incidents, keeping records of PMC staff, carrying out inspections of signed contracts, as well as enforcing possible financial penalties. According to the position of the United States and Great Britain, within the Swiss Initiative, there was a plan to create three working groups including British diplomats and employees of the US Department of Defense, who would designate the structure, sources of financing and the directors of the future international secretariat. Representatives of the US State Department, the Pentagon, as well as leading American and British PMCs were to participate in the work of the international body. The international body would be empowered to conduct international inspections and have the right to withdraw companies' permission for the implementation of professional activities. It is assumed that the headquarters would be located in Geneva. ${ }^{15}$ As of today, these initiatives have been completed with the adoption of the Montreux Document in $2008^{16}$ and the International Code of Conduct for Private Security Service Providers in 2010. ${ }^{17}$

The Montreux Document contains rules and regulations for private military and security companies operating in armed conflict zones. In total, it contains some 70 recommendations on regulating the activities of private contractors in the zones of military conflicts and monitoring compliance with the standards of international law. The document was the result of an international process initiated in 2006 by the Government of Switzerland and the International Committee of the Red Cross. Along with the cover letter of the Permanent Representative of Switzerland to the United Nations, the document was sent to its Secretary General.

The Montreux Document consists of two parts. The first part defines the notion of a private military company. According to the document, PMCs "are private business entities that provide military and/or security services, irrespective of how they describe themselves. Military and security services include, in particular, armed guarding and the protection of persons and objects, such as convoys, buildings and other places; the maintenance and operation of weapons systems; prisoner detention; and advice to or training of local forces and security personnel." 18 The document also mentions three groups of states:

${ }^{15}$ International legal aspects of the use of PMCs. Available at: http://www.modernarmy.ru/article/360/ mejdunarodno-pravovie-aspekty-ispolzovaniya-chvk (accessed 10 April 2016).

${ }^{16}$ Montreux document on relevant international legal obligations and best practices of states concerning the operation of private military and security companies during armed conflicts. Available at: https://www.icrc. org/rus/resources/documents/misc/ihl-montreau.htm (accessed 10 April 2016).

${ }^{17}$ International Code of Conduct for Private Security Service Providers. Available at: http://www.icoca. ch/sites/all/themes/icoca/assets/icoc_russian3.pdf (accessed 10 April 2016).

${ }^{18}$ Montreux document on relevant international legal obligations and best practices of States concerning the operation of private military and security companies in the period of armed conflicts. Available at: https:// 
Contracting States;

- Territorial States (States on whose territory PMCs operate);

- Home States (of incorporation, registration, principal place of management). ${ }^{19}$

The main drawback of the Montreux Document is its declarative nature. Since it is only a sketch for a possible international regulatory framework, its provisions are not mandatory and are of a recommendatory nature.

According to the International Code of Conduct for Private Security Service Providers, "private security companies (PSCs) and private security service providers are any company whose commercial activities include the provision of security services either on its own behalf or on behalf of another, irrespective of how the company describes itself." 20 When signing the Code, the PSC assumes the obligation to "establish within 18 months external independent mechanisms for effective governance and oversight, which will include the Certification of Signatory Companies' compliance with the Code's principles and the standards derived from the Code, beginning with adequate policies and procedures, the Auditing and Monitoring of their work in the field, including Reporting, and execution of a mechanism to address alleged violations of the Code's principles or the standards derived from the Code." In addition, companies that have signed the Code are required to "establish and/or demonstrate internal processes to meet the requirements of the Code's principles and the standards derived from the Code," and "... once the governance and oversight mechanism is established," private security companies and service providers "become certified by and submit to ongoing independent Auditing and verification by that mechanism." They also "make compliance with this Code an integral part of contractual agreements with Personnel and subcontractors or other parties carrying out Security Services under their contracts," and "adhere to this Code, even when the Code is not included in a contractual agreement with a Client." 21

To date, the International Code of Conduct for Private Security Service Providers has been signed by 708 companies.

Compliance with the standards of this International Code of Conduct for Private Security Service Providers is a prerequisite for the signing of any contracts for the provision of private military services at the international level. However, as with the Montreux Document, the International Code of Conduct for Private Security Service Providers does not have mandatory legal force and is recommendatory in nature.

Thus, the Montreux Document and the International Code of Conduct for Private Security Service Providers do not impose restrictions that infringe or, alternately, expand the rules of current international law or national legislations.

Separately, we should mention the legal framework for regulating the phenomenon under study. An important link in this chain is the use of PMCs in Russia. To date,

\footnotetext{
www.icrc.org/rus/resources/documents/misc/ihl-montreau.htm (accessed 10 April 2016).

${ }^{19}$ Montreux document on relevant international legal obligations and best practices of States concerning the operation of private military and security companies in the period of armed conflicts. Available at: https:// www.icrc.org/rus/resources/documents/misc/ihl-montreau.htm (accessed 10 April 2016).

${ }^{20}$ International Code of Conduct for Private Security Service Providers. Available at: http://www.icoca. ch/sites/all/themes/icoca/assets/icoc_russian3.pdf (accessed 10 April 2016).

${ }^{21}$ International legal aspects of the use of PMCs. Available at: http://www.modernarmy.ru/article/360/ mejdunarodno-pravovie-aspekty-ispolzovaniya-chvk (accessed 10 April 2016).
} 
there is no provision in Russian legislation that would directly regulate the activities of PMCs as legal entities.

As a rule, when such pilot projects appear, legislators tend to avoid the specifics and speak in generalities, giving loose, vacuous descriptions of the provisions of the bill.

When the law is created, it may contain two types of services - security and military. From the viewpoint of organizing the activities of the private military sector, the first major question is who the employer of these companies is. Orders for such services can come from various sources:

- government;

- relevant ministries and departments;

- businesses;

- private persons;

- non-governmental organizations, etc.

Naturally, the adoption of such a bill will entail the adoption of changes to other legislative acts of the Russian Federation (the Criminal Code of the Russian Federation, the Tax Code of the Russian Federation, and the Labor Code of the Russian Federation by supplementing them with items associated with international and military law). ${ }^{22}$

Private military companies and related businesses still cannot operate in Russia, first of all due to the lack of a legislative framework. According to the existing Russian legislature, this difficult, challenging and sometimes dangerous occupation has the same status as mercenary activity (Criminal Code of the Russian Federation, chapter 34, article 359. Mercenaries). ${ }^{23}$ Article 208 of the Criminal Code of the Russian Federation is an additional restraining factor in the development of Russian PMCs. It says that the creation of an armed formation is not provided for by federal law, and that the the leadership of such a group or financing one is a crime.

The development of the private military business in Russia would necessitate the urgent adoption of a special law on private military activities, or the refinement of the existing Federal Law "On Private Detective and Security Activities in the Russian Federation," with appropriate amendments to the Criminal Code of the Russian Federation. The former option appears preferable.

An interim step has already been taken.

In July 2007, the State Duma and the Federation Council approved the law "On Procurement of Goods for Federal State Needs," which empowered special units of Transneft JSC and Gazprom OJSC "to use official weapons and special equipment to ensure the protection of goods supplied for federal state needs and facilities for the goods' production, processing, storage and transportation, as well as to protect other property necessary for the performance of state contracts, including during transportation." After Russian President Vladimir Putin signed the bill on August 1, 2007, the security units of Gazprom and Transneft received the right to engage in departmental security services, i.e. in essence the same activity employees of the Ministry of Internal

${ }^{22}$ I. Rakitskaya (2014) Russian Constitutional Law: textbook. Moscow State Institute of International Relations of the Ministry of Foreign Affairs of Russia, Department of Constitutional Law.

${ }^{23}$ Russian Constitutional Law (eds Elena A. Kremyanskaya, Tamara O. Kuznetsova, Inna A. Rakitskaya). Cambridge Scholars Publishing. 
Affairs have. However, since that moment, the institutionalization of PMCs in Russia has stagnated legally and remains totally unclear. So far, only a few Russian PSCs have been able to gain some experience as PMCs in Iraq - Oryol-Antiterror, Tigr Top-Rent Security, Redut Antiterror, and Feraks. ${ }^{24}$

As of today, Russian PMCs are practically prohibited from competing in the world market for military services, and without state support, it will not be easy to enter.

\section{Largest PMCs as of 2016}

We will list a number of PMCs that currently take the most active part in international conflicts. It should be noted that out of over 400 private currently existing companies that earn on war, only a few are widely known. Therefore, we list the most famous of them:

- Blackwater ${ }^{25}$ /Academi (USA)

The company was founded by retired US Navy Special Forces officer Eric Prince. It has at its disposal a modern testing ground, helicopters, boats, and patrol ships which are used by the US Coast Guard. It builds complexes for training its own employees, and also works under contract with the US Armed Forces and special services, and trains their personnel.

The company formerly known as Blackwater became widely known after an incident in the Iraqi city of Fallujah in April 2003, when its employees came into opposition with the local population, resulting in gunfire. As a result of the fighting, four employees of the company were captured by extremists and brutally killed. In response, the troops of the united coalition took the city by storm, which resulted in numerous casualties among civilians. Only in 2007, it received more than $\$ 1$ billion from the US government for carrying out special assignments in Iraqi territory. The company has a branch office in Tashkent, Uzbekistan. It was renamed Xe Services in 2009 and Acade$\mathrm{mi}$ in 2011. The activities of this company in the territory of Ukraine will be discussed in the second part of this work.

- Kellog, Brown and Root (USA)

KBR is a structural unit of Halliburton, the company once led by former US Vice President Dick Cheney. It actively participated in the Yugoslav conflict as a logistics company and as the main structure for training personnel for the local police. It also engaged in the protection of oil fields and industrial facilities in Iraq.

- Groupe-EHC (France)

This PMC was established in 1999 by former French army personnel. This is the first French military company to be represented in the United States. The company operates in high-risk regions, primarily in the former French colonies and African countries. It has experience in Iraq, Pakistan, Afghanistan, Indonesia, and Poland.

- MPRI International (Military Professional Resources) Inc. (USA)

The company provides a wide range of integrated services for the US and foreign armed forces in more than 40 countries. It provides training and support programs for

${ }^{24}$ I. Konovalov, O. Valetsky (2013) Evolution of Private Military Companies. Pushkino: Center for Strategic Situations.

${ }^{25}$ Foreign sources often use a divided version of the name of the company - Black Water. Author's note. 
employees of special forces, programs to stabilize conflict situations in various regions, training on the management of state military personnel, analytical support for special operations, and other services. It conducts security programs in Afghanistan, Kuwait, Bosnia, and Equatorial Guinea.

In addition to its main functions, MPRI International assists public authorities in developing strategies for effective information analysis, and provides support for research and public opinion assessment. It also has a program to combat corruption, which includes the creation and functioning of a special institute of inspectors general in each ministry and department to identify manifestations of corruption both in stable and unstable conditions.

To date, the company is managed by General Carl Vuono, former Chief of Staff of the Expeditionary Force of the US Armed Forces during operations in Panama and Desert Storm, and General Ed Soyster, former head of the US Military Intelligence Agency. ${ }^{26}$

\section{Participation of PMCs in the civil war in Ukraine}

The Ukrainian conflict continues to attract the attention of the public and will have a long-term destabilizing effect on the region's security. One of the most discussed issues both in the media and in the scientific and political discourse is the participation of PMCs in the civil war in Ukraine.

We should warn that it does not appear possible to cover the issue of the activities of PMCs (especially foreign ones) in Ukraine in full. Their activities are discussed based mainly on open sources of data, as well as by comparing information and inferencing.

PMCs appeared in Ukraine long before the start of the civil war in the country. However, it is during the development of this crisis that interest in them appeared. Let us emphasize that Ukraine was one of the first countries to ratify the Montreux Document considered above. The PMCs operating in Ukraine should be divided into two groups. The first includes those PMCs that can be called local, because they are registered in Ukraine, and their employees are mostly Ukrainians. The second group of PMCs includes companies that work in Ukraine but are registered abroad, owned by foreigners and serve their interests.

We will not dwell on the activities of PMCs in Ukraine during the pre-crisis period; we will give only a general overview of their activities.

Back in the 1990s, private security companies began to appear in Ukraine as well as in other former Soviet republics. They constituted the power core of the most powerful criminal structure that had become legitimate - that comprised of former state administrative officials. Private security eventually defeated the less organized and economically weaker forces of the simple gangster world. The natural victory was on the side of the private security companies controlled by national-level oligarchs and bureaucrats, which conquered "lawlessness" in a few years. ${ }^{27}$

${ }^{26}$ Private Military Companies - Mercenaries of the XXI Century. Available at: http://politrussia.com/ vooruzhennye-sily/chastnye-voennye-kompanii-469/ (accessed 10 April 2016).

${ }^{27}$ Conflict in Ukraine and Private Military Companies. Available at: http://road2life.in.ua/publ/3 (accessed 10 April 2016). 
The PMCs as we know them began to appear in Ukraine around 2010. The largest Ukrainian companies include Omega Consulting Group, Artan Group, Albatros, Vega, and others. The Odessa company Albatros and the Nikolayev company Vega specialize in protecting ships from piracy. In relation to the latter, there was information regarding the participation of its employees in the antiterrorist operation (ATO) in Donbass. According to the available data, both PMCs work abroad ensuring the safety of the maritime transport of foreign ship owners. Official information is very scarce. PMC Omega Consulting's headquarters are located not far from Kiev, in Slavutich. On its website, the Ministry of Defense of Ukraine is listed among its customers. Officially, the company is engaged in the security business and training of bodyguards.

Artan Group, another PMC, is a very powerful outfit that is engaged in the protection of numerous facilities, military operations, the training of bodyguards, and guarding of ships. Among the facilities guarded by Artan employees are many that once belonged to the closest associates of former President V. Yanukovych. Artan Group even received a letter of recommendation ??from the post-coup Ukrainian Minister of Education and Science S. Kvit, a former member of the paramilitary organization Stepan Bandera Tryzub. This PMC supported the launch of the outright nationalist PMC Tamplier, whose employees were seen in the retaliatory battalion Aidar. Tamplier cooperates with Ukrainian nationalists and various right-wing radical volunteer organizations (such as Lvivska Brama). Media support is provided to Tamplier by Ukrainian nationalist Internet resources. ${ }^{28}$

As of today, there is no accurate data on whether Ukrainian PMCs directly participate in the so-called 'anti-terrorist operation' (ATO) in the eastern regions of Ukraine, or whether they advise the government on certain issues. To date, we know for certain about the participation of Omega Consulting, headed by A. Kebkalo, in the armed conflict in Donbass. In the spring of 2014, the company had open vacancies for advisor jobs, which were scheduled to be filled by May 1, 2014. One of the eligibility requirements was that applicants be registered as living in Ukraine's eastern Kharkiv, Donetsk, or Luhansk regions. Officially, the company recognized its participation in operations for the "emergency withdrawal of the Customer's personnel from the Autonomous Republic of Crimea and Donbass." ${ }^{29}$ At the moment, the PMC's public relations department recognizes the existence of a contract relating to activities in the Donetsk and Lugansk regions (which seek independence from Ukraine), though it claims that it has no state orders - all contracts were signed with private individuals or enterprises. ${ }^{30}$

Let us turn to the activities of foreign PMCs in Ukraine. Since 1992, a branch of G4S, one of the largest PMCs in terms of staff size, has been operational in the country. The multinational company has Danish roots and is headquartered in the UK and trades on the British and Danish stock exchanges. It recruits experts in intelligence and military affairs, operating in over 100 countries with a staff of 675 thousand people,

${ }^{28}$ Morgenstern A. What Are Private Military Companies And What Are They Doing in Ukraine. Available at: http://spinoza.in/analytics/chto-takoe-chastnye-voennye-kompanii-i-chto-oni-delayut-na-ukraine.html (accessed 10 April 2016).

${ }^{29}$ A. Dobrovolsky. Private Military Companies - Mercenaries of the XXI Century. Available at: http:// politrussia.com/vooruzhennye-sily/chastnye-voennye-kompanii-469/ (accessed 10 April 2016).

${ }^{30}$ V. Neelov. Private Military Companies and the War in the South-East of Ukraine. Available at: http:// www.conjuncture.ru/category/pmc/ (accessed 10 April 2016). 
dwarfing most of the national armies of European powers. (you can add http://www. bbc.com/news/uk-39968776) G4S owns armored vehicles, aircraft, maritime transport, unmanned vehicles, various means of electronic warfare, and reconnaissance technology. This company deals with a wide range of military and security services, which makes it independent, even in solving military and political problems. Another giant in the military business is L3, which is engaged in the security of mobile and information communications in Ukraine. Leidos, one of the oldest and most influential private military corporations, also works in Ukraine and maintains connections with activists from the EuroMaidan movement (which launched the February 2014 coup) both in the diaspora and in Ukraine itself. ${ }^{31}$

After the coup d'état, Ukraine's proxy confrontation between the West on one side and Russia on the other descended into civil war. One of the most important tools used in this conflict by Western countries, primarily the US, is the PMCs. An analysis of open sourced data suggests that since February-March 2014, there have been PMCs in Ukraine from a number of countries, primarily the United States, Poland, and the UK, under contracts with the Kiev central government as well as individuals and institutions. They have performed a number of functions: operational and strategic planning, the training of command and personnel, as well as the protection of individuals and individual objects. Ukraine has traditionally been attractive to PMCs. Thanks to an advantageous geographical location and due to regional peculiarities, Odessa has become one of the largest trans-shipment points for people wishing to go to war. In this regard, foreign PMCs were active here until their own representative offices were opened. However, if before the events of 2013-2014 Ukraine was attractive for foreign military contractors mainly as a source of inexpensive, highly-trained staff, the coup and the events that followed allowed them to enter the market in a new way: as contractors carrying out specific orders on the part of a number of Ukrainian entrepreneurs and oligarchs, as well as the central government in Kiev. ${ }^{32}$

Do these or other PMCs participate in the hostilities in the South-East of Ukraine? There are serious differences in opinions concerning their role. It was primarily proRussian media outlets that that claimed the participation of American PMCs in the Ukrainian crisis. They mentioned the American PMCs Blackwater and Greystone. A video was published online in which several people wearing weird military uniforms were walking down the street in Donetsk in March 2014. ${ }^{33}$ Pro-Russian websites were quick to identify the people in the video as Blackwater employees, although at that time the company had already ceased to exist and had been transformed into several other private military and security companies. This case of mistaken identity is best explained by the fact that the Blackwater is the most famous brand; the company carried out a number of high-profile military operations against civilians and rebel forces in Iraq. The actions of Blackwater in Iraq were well-known to the Russian audience, so drop-

\footnotetext{
${ }^{31}$ V. Neelov. Private Military Companies and the War in the South-East of Ukraine. Available at: http:// www.conjuncture.ru/category/pmc/ (accessed 10 April 2016).

${ }^{32}$ Ibid. xgxj_6Qo

${ }^{33}$ See: https://www.youtube.com/watch?v=1VFMAIv8yvA и https://www.youtube.com/watch?v=UD_
} 
ping the name of this odious force in the conflict in Ukraine was extremely tempting for Russian propaganda outlets. Additionally, pro-Russian information websites and services, as well as online resources supporting the unrecognized Donetsk People's Republic and Lugansk People's Republic, provided information about the participation in the armed conflict of the employees of Greystone, a subsidiary of Academi LLC (formerly known as Blackwater). For a short time, the company's website posted an announcement about a good job in Russia, but in the spring of 2014, this announcement disappeared. No convincing data supporting the participation of this PMC in the conflict has been found so far, although the rebel forces reported losses in this military company. A little later, unofficial sources provided information that 20 mercenaries had been captured by the militia in the Slavyansk region. According to some reports, the captive mercenaries were from Graystone, others claim they were from another American PMC - Academi. Also, websites supporting the Donetsk People's Republic and Lugansk People's Republic reported on the participation of the Polish PMC ASBS Othago (Analizy Systemowe Bartlomiej Sienkiewicz) in the military operations on the side of the ATO forces. This information was not confirmed either. ${ }^{34}$

Let us emphasize that there is no reliable information about the direct participation of the personnel of foreign PMCs in combat operations. There are assumptions, hypotheses, and suspicions. None of the foreign PMCs has confirmed the participation of their employees in the hostilities in Donbass. This is understandable, as no party to the conflict is likely to condone their participation in it. The US government stated that there is no US military involvement in Ukraine, followed by a similar statement from the Polish authorities. Moreover, the management of Greystone stated that its employees were not and had never been in Ukraine.

So far, the information on the participation of PMCs in hostilities in the east of the country has come only from unofficial sources referring to the leaders of the self-proclaimed republics. First of all, we are talking about the data of the officials of the Donetsk People's Republic and Lugansk People's Republic, who reported on the participation of foreign PMCs in the hostilities in Donbass. The peak of information activity on the subject of the presence of PMCs in Ukraine was during March-June 2014, immediately after the coup d'état and the beginning of pro-Russian independence stirrings in the SouthEast of the country. At the first stage, the geography of the PMCs' presence basically coincided with the geography of protest activity: the Kharkiv, Donetsk, Luhansk, and Dnipropetrovsk regions. In addition, PMC staff were spotted in Kiev.

Let us repeat once again that at the moment there is no reliable information on the direct participation of PMC employees in the Ukrainian conflict as combatants. Actually, there is nothing weird about this. On the contrary, this is one of the important advantages of PMCs compared to state armies. PMCs can act as covertly as they see fit.

Nevertheless, according to some experts, the foreign private military company specialists can still legally take part in the military operations on the side of the Ukrainian army, but as advisers. This, however, is not a secret.

${ }^{34}$ V. Neelov. Private Military Companies and the War in the South-East of Ukraine. Available at: http:// www.conjuncture.ru/category/pmc/ (accessed 10 April 2016). 
The main tasks for the PMCs hired at this stage in the above-mentioned regions include the training and coordination of local law enforcement officers, as well as special units. Their objective is the elimination of protest activities in these regions, as well as the evacuation and escort of individuals and personnel from the territories covered by the uprising. Similar tasks were previously performed in Iraq, Afghanistan, Bosnia and Herzegovina, Kosovo and some other regions by the following foreign companies: DynCorp (USA), Academi (USA), Greystone Limited (USA), and Erinys (Great Britain). We cannot state unequivocally that the employees of these companies were involved in the implementation of these missions, but the participation in previous similar conflicts and the nature of incoming information allows us to speak of a high probability of the presence of these companies.

The next period that witnessed foreign PMC activity in Ukraine is May-August 2014. This period was marked by the most active phase of military operations in Donbass, in 2014. It is very likely that the employees of foreign companies prepared and coordinated activity during a number of AFU military operations (Armed Forces of Ukraine) during that year's summer campaign.

Nevertheless, open sources of information provide data on losses of foreign PMCs in Ukraine: ASBS Othago (Poland) lost 144 people; Graystone (USA) lost 60 people; and Academi (USA) lost 130 people. ${ }^{35}$ Information about foreign combatants who have been killed is regularly received from the militia of the Donetsk People's Republic and Lugansk People's Republic. Although it does not appear possible to establish their status, the probability that these are PMC employees is not high: the nature of the functions performed by these companies most often does not involve direct participation in combat.

The next stage of the conflict was September 2014 - January 2015, the period after the conclusion of the first Minsk agreements. At this time there was a decline in information activity related to PMCs in Ukraine. At the same time, the nature of the Ukraine Freedom Support Act dated December 12, 2014, suggested that, if implemented, US PMCs will be actively involved for training and strategic planning, as well as the supply and servicing of military equipment. Such functions can be performed by both MPRI (operations and strategic planning) and Kellog Brown \& Root (combat service and technical support, training in servicing the supplied equipment).

\section{Conclusion}

Theoretically, the use of PMCs gives the state immunity from international law and even local laws when pursuing counter-insurgency and militaristic foreign policy objectives. It is easy to imagine the normative conduct of military operations by PMCs not in terms of a political conflict or the rules of war, but as a matter of contract compliance between two consenting parties. Accordingly, where corporate law is in force, no one, not even the UN, can demand full publicity and legal transparency. A possible answer to any reproaches in this situation is that the state does not interfere in the internal

${ }^{35}$ How and whom are foreign private military companies fighting in Ukraine? Available at: http:// chvkmar.ru/category/novosti (accessed 10 April 2016). 
affairs of PMCs. Thus, from a legal and diplomatic point of view, even the decision to "billet" the army to private military companies may appear efficient. Evidence of this can be found in the policies of the United States and some European countries.

Involving private military contractors in an internal political conflict certainly creates additional complications for its government, if it hopes to restore domestic harmony. One shouldn't be fooled about the true purposes of using foreign contractors and their support by Western countries: any activity in any country is primarily dictated by the interests of its internal elites, rather than by the interests of democratic reforms, especially outside the developed world. Heads of state undoubtedly have a long dirty tradition of using mercenaries, including for suppressing popular uprisings. This tradition was developed by the United States as well, and Washington pursued different goals in each specific situation. ${ }^{36}$

First, US efforts in the 1990s and early 2000s, including in the information sphere, created an image of soldiers for hire that was neutral, if not positive. Now that the United States has used hundreds of thousands of military contractors in high-profile armed conflicts over the past decade, there is little reason for the US itself to condemn the use of similar structures by other sovereign states.

The US continues to use private military forces despite repeated instances of contractors' involvement in abuses, senseless murders of civilians, and even the work of hired assassins for the CIA. Given the widest interpenetration of business in the US power and a legal system that condones corporate political lobbying, the US government has no legal or moral grounds to demand the restriction of the use of military contractors by the governments of other countries, even though those other governments mainly use foreign military contractors to prevent or suppress internal democratic movements.

Secondly, it was the US that created and subsidized the private military industry. By hiring contractors and paying them billions of dollars under contracts, the US breathed life and developed a private military industry, which enabled it to gain experience and professional contacts. It should be noted that the US also allowed allegedly authoritative corporate contractors to conclude subcontract agreements with local security organizations, including ones with dubious staffing policies, thus bringing cheaper and less professional military services to the market.

After the state paid in full for the costs of keeping PMCs in Afghanistan and Iraq, and after the latter gained huge profits from their activities, neither large private military corporations nor their smaller subcontractors will disappear from the world economy. Moreover, they will also occupy a stable niche in it. This is confirmed by the dynamically developing security and private military industries, which have already gone beyond purely governmental contracts and are opening up new business opportunities. It is most likely that given the successful US example, other countries will develop the practice of using private military contractors as well. Thus, a fundamentally new tool is being shaped for protecting nations' interests and projecting them abroad.

${ }^{36}$ Use of private military companies in international conflicts. Available at: http://speccom. livejournal.com/1241.html (accessed 10 April 2016). 
The most obvious example of such positioning is our analysis of the use of PMCs in the armed conflict in Ukraine, where the government of Kyiv and private individuals (mainly oligarchs) concluded contracts with PMCs, primarily from the USA and Poland. As the armed confrontation developed, the PMCs performed a number of functions: the protection of facilities and persons, operational and strategic planning, the training of personnel at all levels, and the evacuation and escort of persons and personnel. The active participation of PMC personnel directly in the hostilities in the Donbas was not recorded due to a number of reasons, principally because there were a sufficient number of motivated nationalist volunteers in the ranks of the National Guard and volunteer battalions, which also required training.

Due to the lack of legal grounds for the United States to render direct assistance to Ukraine, as well as supply lethal weapons, Washington resorted to the active use of a non-state instrument - PMCs. As the analysis demonstrates, these organizations provided the widest range of services to improve the Armed Forces of Ukraine, the National Guard and other law enforcement agencies in Ukraine.

Foreign PMCs have sufficient physical resources on the territory of Ukraine, as well as significant connections and work experience. Over the course of its 21 years of existence, the Ukrainian Armed Forces had experienced a lightning-fast process of degradation, as did other power structures. Amid the civil war, which began from approximately May 2014, it became obvious that the power structures of Ukraine had lost the ability to organize and conduct military activities. The assistance of the Western PMCs was therefore reduced mainly to advising the military and political leadership of Ukraine.

It should be recognized that in the short and medium term, the use of PMCs by government and private entities is bound to increase due to the lack of serious intentions to resolve the conflict peacefully. The companies that already have substantial physical resources and connections in the country (besides those mentioned above) have a solid chance to enter the Ukrainian market in a new capacity. At the same time, PMCs registered in Ukraine have so far shown themselves to be relatively inactive. There is only official information about one Ukrainian PMC that has performed tasks related to participation in this conflict. However, in the medium term, we can expect the development of Ukraine's local PMC market.

We can probably conclude that apparently there are foreign PMCs in Ukraine after all. However, we can neither confirm nor refute this. According to some experts, the participation of the employees of these companies is limited to the role of advisers. In the opinion of others, mercenaries have taken direct part in hostilities.

Such discrepancies in the expert environment are the result of a number of methodological difficulties encountered by those studying the activities of PMCs. We would like to draw attention to these problems. First, studying PMCs is very difficult due to a narrow range of sources and their questionable origin. Basically, we have to be satisfied with secondary sources. Second, we should note the high politicization of this problem, which also leaves an imprint on the quality of information that the researcher has to deal with. A vast array of available information is propaganda and should be considered part of an information war. This necessitates great care when studying related literature. Third, the categorical and terminological apparatus of the research problem 
has not settled yet; private military companies are commonly incorrectly equated with mercenaries. Discrepancies related to this issue lead to errors in verifying that PMC personnel are engaged in military operations in various countries, including Ukraine. This can be quite acceptable in relation to PMC personnel, who, for example, went on vacation and went to fight in a certain flash point in personal capacity. In such cases, they cannot be considered employees of PMCs, but rather mercenaries.

To summarize, we will note that the main advantages of PMCs are their promptness, responsibility, efficiency, professionalism and undeniable financial advantage. PMCs are an alternative to the use of state military structures and criminal organizations. They provide guarantees and insurance in unstable areas, quick problem solving, and efficient risk management. It is often more advantageous to sign a contract with a PMC for a specific task than to send a security company associated with an oil or gas giant, or send troops and maintain garrisons. On the other hand, if the state does not want to advertise its participation in a given conflict or project, or wants to shift the dirty work to somebody else, which happens often enough during war, PMCs are excellent for these purposes as well.

\section{References}

Alikin A. (2014) ChVK - jeto ochen' jeffektivnyj instrument vlijanija [PMCs are a Very Effective Tool of Influence]. Available at: http://rusplt.ru/society/voennie-chastniki-8795.html (accessed 10 April 2016). (In Russian.)

Apuhtin J.S. (2009) Chastnye voennye kompanii: novaja cel' politicheskoj kriminologii [Private Military Companies: a New Goal of Political Criminology]. Criminology: Yesterday, Today, Tomorrow, no 2 (17). (In Russian.)

Cepkov N. (2015) Chastnye voennye kompanii: kratkij obzor mirovogo i rossijskogo regulirovanija [Private Military Companies: A Brief Overview of International and Russian Regulation]. Available at: https://zakon.ru/blog/2015/12/14/chastnye_voennye_kompanii_kratkij_obzor_mirovogo_i_rossijskogo_regulirovaniya (accessed 10 April 2016). (In Russian.)

Kanchukov S.A. (2012) Chastnye voennye kompanii - pomoshh' ili obuza dlja Rossii? [Private Military Companies - Help or Burden for Russia?]. Available at: http://www.iarex.ru/articles/28444.html (accessed 10 April 2016). (In Russian.)

Konovalov I.P., Valeckij O.V. (2013) Jevoljucija chastnyh voennyh kompanij [Evolution of Private Military Companies]. Pushkino: Centr strategicheskoj konjunktury, p. 47. (In Russian.)

Kremyanskaya E.A., Kuznetsova T.O., Rakitskaya I.A. (eds) (2014) Russian Constitutional Law. Cambridge Scholars Publishing, p. 134.

Rakitskaja I.A. (2014) Konstitucionnye osnovy Rossijskoj Federacii [Russian Constitutional Law: Textbook] / I.A. Rakitskaja, E.A. Kremjanskaja, T.O. Kuznecova (eds.). Moscow: MGIMO-Universitet. (In Russian.)

Singer P. (2005) Outsourcing War. Foreign Affairs. 1 March. Available at: http://www.brookings.edu/ views/articles/fellows/singer20050301.htm (accessed 10 April 2016).

Volevodz A.G. (2009) O mezhdunarodnyh iniciativah v sfere pravovogo regulirovanija dejatel'nosti chastnyh voennyh i ohrannyh kompanij [On International Initiatives in Legal Regulation of the Activities of Private Military and Security Companies]. International Criminal Law and International Justice, no 1, p. 14. (In Russian.) 


\title{
Феномен частных военных компаний в военно-силовой политике государств в XXI в. ${ }^{1}$
}

\author{
К.П. Курылев, Е.В. Мартыненко, Н.П. Пархитько, Д.В. Станис
}

Курылев Константин Петрович - д.и.н., доцент кафедры теории и истории международных отношений Российского университета дружбы народов (РУДН); Российская Федерация, 117198, Москва, ул. Миклухо-Маклая, д. 6; E-mail: kurylev_kp@rudn.university.ru

Мартыненко Елена Викторовна - д.п.н., профессор, проректор Российского университета дружбы народов (РУДН); заведующая кафедрой теории и истории журналистики РУДН; РФ, 117198, Москва, ул. Миклухо-Маклая, д. 6; E-mail: martynenko_ev@pfur.ru

Пархитько Николай Петрович - к.и.н., доцент кафедры теории и истории журналистики Российского университета дружбы народов (РУДН); Российская Федерация, 117198, Москва, ул. Миклухо-Маклая, д. 6; E-mail: parkhitko_np@rudn.university.ru

Станис Дарья Владимировна - к.э.н., доцент кафедры государственного и муниципального управления Российского университета дружбы народов (РУДН); Российская Федерация, 117198, Москва, ул. Миклухо-Маклая, д. 6; E-mail: stanis_dv@rudn.university.ru

В статье рассматриваются два основных аспекта феномена частных военных компаний. Первый - это историко-правовой статус частных военных компаний (private military companies) (ЧВК - РМС), изменяюшийся с течением времени. Зародившись после окончания Второй мировой войны, данное явление окончательно оформилось к середине 1990-х годов. В первое же десятилетие ХХІ в. ЧВК стали демонстрировать не только военную активность в разных регионах мира, но и проявлять черты самостоятельных экономических акторов, способных занять определенную нишу в военном сегменте мировой экономики. Во второй части статьи рассматривается практическая деятельность ЧВК на примере их участия в конфликте на Украине в ходе начавшейся там гражданской войны после совершенного в феврале 2014 г. государственного переворота, отстранения от власти законно избранного президента В.Ф. Януковича и прихода к власти националистоврадикалов. Отмечается, что украинский кризис выступает в качестве одного из многих примеров использования ЧВК. При этом, как показано в исследовании, на территории Украины представлены наиболее могущественные ЧВК мира, что является свидетельством крайней важности тех процессов, которые происходят на Украине, с точки зрения интересов доминантных акторов современной международной системы, вовлеченных в украинские дела.

Ключевые слова: частная военная компания (ЧВК); наемники; Документ Монтрё, Украина; вооруженный конфликт; гражданская война.

Для цитирования: Курылев К.П., Мартыненко Е.В., Пархитько Н.П., Станис Д.В. Феномен частных военных компаний в военно-силовой политике государств в XXI в. // Вестник международных организаций. 2017. T. 12. № 4. C. 130-149. DOI: 10.17323/1996-7845-2017-04-130

\section{Источники}

Аликин А. (2014) ЧВК - это очень эффективный инструмент влияния. Режим доступа: http://rusplt. $\mathrm{ru} /$ society/voennie-chastniki-8795.html (дата обращения: 10.04.2016).

Апухтин Ю.С. (2009) Частные военные компании: новая цель политической криминологии // Криминология: вчера, сегодня, завтра. № 2 (17).

\footnotetext{
${ }^{1}$ Статья поступила в редакцию в мае 2016 г.
} 
Волеводз А.Г. (2009) О международных инициативах в сфере правового регулирования деятельности частных военных и охранных компаний // Международное уголовное право и международная юстиция. № 1. С. 14.

Канчуков С.А. (2012) Частные военные компании - помощь или обуза для России? Режим доступа: http://www.iarex.ru/articles/28444.html (дата обращения: 10.04.2016).

Коновалов И.П., Валецкий О.В. (2013) Эволюция частных военных компаний. Пушкино: Центр стратегической конъюнктуры. С. 47.

Ракитская И.А. (2014) Конституционные основы Российской Федерации: учеб. пособ. / под ред. И.А. Ракитской, Е.А. Кремянской, Т.О. Кузнецовой. М.: МГИМО-Университет. С. 136.

Цепков Н. (2015) Частные военные компании: краткий обзор мирового и российского регулирования. Режим доступа: https://zakon.ru/blog/2015/12/14/chastnye_voennye_kompanii_kratkij_obzor_ mirovogo_i_rossijskogo_regulirovaniya (дата обращения: 10.04.2016).

Kremyanskaya E.A., Kuznetsova T.O., Rakitskaya I.A. (eds) (2014) Russian Constitutional Law. Cambridge Scholars Publishing. P. 134.

Singer P. (2005) Outsourcing War // Foreign Affairs. 1 March. Режим доступа: http://www.brookings.edu/ views/articles/fellows/singer20050301.htm (дата обращения: 10.04.2016). 